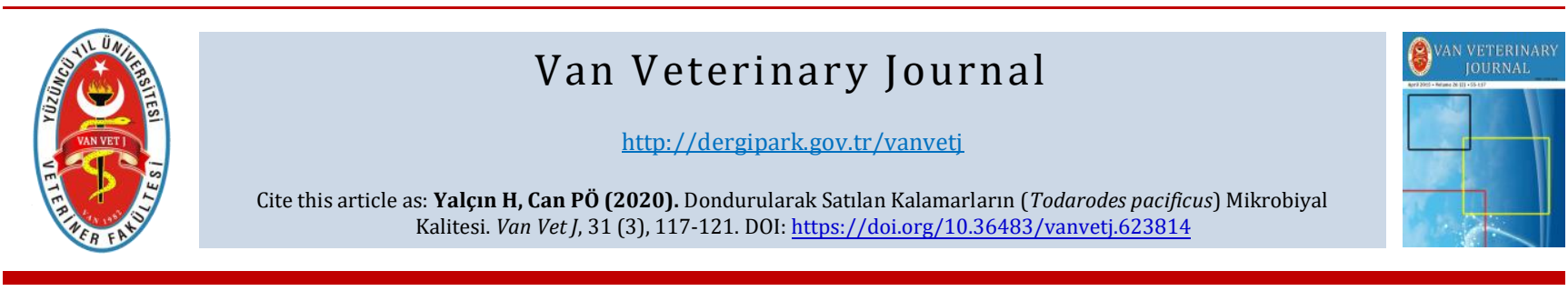

\title{
Microbial Quality of Frozen Retail Squid (Todarodes pacificus)
}

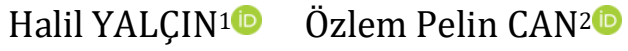 \\ ${ }^{1}$ Burdur Mehmet Akif Ersoy University, Faculty of Veterinary Medicine, Department off Food Hygiene and Technology, Burdur, Turkey \\ ${ }^{2}$ Cumhuriyet University, Faculty of Engineering, Department of Food Engineering, Sivas, Turkey \\ Accepted: 08.05.2020
}

Received: 24.09 .2019

ABSTRACT In this study, cleaned and frozen squid (Todarodes pacificus) samples were examined for E. coli, Pseudomonas spp., L. monocytogenes and coagulase (+) S. aureus. One hundred ring-shaped squid samples, which were frozen in styrofoam plates, were collected from different sale points and brought to the laboratory under the cold chain. Each styrofoam dish containing approximately $500 \mathrm{~g}$ of ring squids in $6-8 \mathrm{~cm}$ diameter was regarded as one sample. In the study, 7 samples of E. coli (7\%), 10 samples of Pseudomonas spp. (10\%), 8 samples of coagulase $(+) S$. aureus (8\%) and 5 samples of $L$. monocytogenes $(5 \%)$ were determined in all samples examined. The highest number of E. coli, Pseudomonas spp. and coagulase (+) $S$. aureus in squid samples were $4.7 \times 10^{3} \mathrm{cfu} / \mathrm{g}, 7.0 \times 10^{2} \mathrm{cfu} / \mathrm{g}$ and $8.9 \times 10^{2} \mathrm{cfu} / \mathrm{g}$, respectively. Results indicate that, some of the squid samples were contaminated with bacteria that would endanger public health. It has been showed that microbiological controls of squid sold in the market should be performed frequently and precautions should be taken to prevent contamination during production.

Keywords: Squid, Microbial Quality, Hygiene, Public Health, S. aureus

öz

\section{Dondurularak Satılan Kalamarların (Todarodes pacificus) Mikrobiyal Kalitesi}

Bu çalışmada, temizlenmiş ve dondurulmuş kalamar (Todarodes pacificus) örnekleri E. coli, Pseudomonas spp., L. monocytogenes ve koagülaz (+) S. aureus açısından incelenmiştir. Halka şekli verilen ve strafor tabaklarda dondurularak satılan 100 adet kalamar örneği farklı satıș noktalarından toplanarak, soğuk zincir altında laboratuvara getirilmiștir. Yaklaşık olarak $500 \mathrm{~g}$ ağırlı̆̆ında ve içerisinde 6-8 cm çapında halka kalamar bulunan her strafor tabak bir örnek olarak değerlendirilmiștir. Çalışmada incelenen örneklerin 7'sinde (\%7) E. coli, 10'unda (\%10) Pseudomonas spp., 8'inde (\%8) koagülaz (+) S. aureus ve 5'inde (\%5) L. monocytogenes tespit edilmiștir. Kalamar örneklerinde en yüksek E. coli, Pseudomonas spp. ve koagülaz (+) $S$. aureus sayısı sırasıyla, $4.7 \times 10^{3} \mathrm{kob} / \mathrm{g}, 7.0 \times 10^{2} \mathrm{kob} / \mathrm{g}$ ve $8.9 \times 10^{2} \mathrm{kob} / \mathrm{g}$ olarak tespit edilmiştir. Yapılan incelemeler sonucunda, kalamar örneklerinin bir kısmının halk sağlığını tehlikeye sokacak bakterilerle kontamine olduğu belirlenmiştir. Piyasada satılan kalamarların mikrobiyolojik kontrollerinin sıklıkla yapılması ve üretim sırasında kontaminasyonun önüne geçecek tedbirlerin alınması gerektiği ortaya konulmuştur.

Anahtar Kelimeler: Kalamar, Mikrobiyal Kalite, Hijyen, Halk Sağlığı, S. aureus

\begin{abstract}
GíRiş
Su ürünleri, insanların sağlıklı beslenmesi açısından gerekli bileşenleri istenilen düzeyde bulundurmaları yanı sıra iyi bir protein (\%13.0-19.2) kaynağıdırlar (Deng ve ark. 2012). Kalamarlar, Cephalopoda sinıfindan olup Teuthoidea takımında yer alan ülkemiz sularında önemli bir potansiyele sahip yumuşakçalardır. Türkiye İstatistik Kurumu verilerine göre kalamar üretimimiz 523 tondur (TÜíK 2019). Diğer kafadan bacaklılarda olduğu gibi, kalamarların da manto ve kolları yenmektedir. Isıl işlem uygulanarak hazırlanmasının yanında çiğ ve yarı kuru halde de tüketilmektedir. Avcılı̆̆ın yoğun yapıldığı dönemlerde elde edilen deniz ürünleri sonraki süreçlerde satılmak için donmuş olarak depolanmaktadır (Deng ve
\end{abstract}

ark. 2012). Bakteriyel, viral, paraziter ya da kimyasal faktörlerle gıdaların kontamine olmasıyla insanlarda ortaya çıkan hastalıklar dünyada geniş bir yelpaze içinde yer almaktadır (Teplitski ve ark. 2009). Taze kalamar $\% 80$ 'den fazla su içerdiğinden mikrobiyal faaliyete oldukça uygundur ayrıca işlenmesinde elle müdahale olduğundan patojen bakterilerce kontaminasyonu büyük risk teşkil etmektedir (Choi ve ark. 2012). Gıda sanayiinin gida güvenliği konusunda ilerlemesine ve bilinçli tüketici kitlesinin oluşmasına rağmen deniz ürünlerinde Salmonella spp., E. coli, L. monocytogenes, Staphylococcus aureus ve patojenik vibrio türleri gibi bakteriler tespit edilmektedir (EFSA 2010; Beleneva 2011). Buna sebep olarak; gıdaların daha az işlenmesi ile ilgili taleplerin artması, global pazarların oluşması, uzun nakliye 
ihtiyaçları, soğuk zincirin kırılması, patojen bakterilerin varlığına ve çoğalmasına sebep olacak yeni faktörlerin (antibiyotik kullanımı vs.) şekillenmesi gösterilmektedir (Rendueles ve ark. 2011; Vázquez-Sánchez ve ark. 2012). Su ürünleri, kaynağında ya da taşıma ve işleme sırasında birçok mikroorganizmayla kontamine olabilir. Önemli bir hijyen faktörü olan $E$. coli bağırsak kökenlidir. $\mathrm{Bu}$ bakterinin gıdalarda varlığı işleme sırasında yetersiz hijyeni veya işlem sonrasında çapraz bulaşmayı gösterir. Deniz ürünleri, insan listeriozisinin ve stafilokokkal infeksiyonlarının sebeplerinden biri olarak görülmektedir (Liston 1990; Rocourt ve Cossart 1997). İnsan eliyle yetiştirilmekte olan kültür balıklarının \%80'nin $L$. monocytogenes ile kontamine olabileceği belirtilmiştir (Fenlon 1999). Araștırmacılar tarafından deniz suyu ve deniz canlılarında L. monocytogenes'in çoklu direnç gösteren suşlarının varlığı rapor edilmiştir (Rodas-Suárez ve ark. 2006).

S. aureus dünya genelinde insanlarda gıda kaynaklı hastalıklara sebep olan bakterilerin bașında gelmektedir (EFSA 2010; Bogdanovicova ve ark. 2017). Güney Kore'de kurutulmuş kalamarlarda $S$. aureus (1.00 log kob/g) ve koliform (0.90 log kob/g) bakterileri tespit edilmiș ve bunların kaynağının ham madde ve hijyen kurallarına dikkat edilmeden yapılan işleme sürecinde olabileceği ileri sürülmüştür (Lee ve ark. 2015). Vázquez-Sánchez ve ark. (2012), satış noktalarından temin ettikleri deniz ürünlerinin ortalama \%25'nin $S$. aureus ile kontamine olduklarını belirlemişlerdir. Araştırmacılar (Herrera ve ark. 2006) bu oranın taze ürünlerde $\% 43$, donmuş ürünlerde ise \%30'lara kadar çıtığını ortaya koymuşlardır. Stafilokokkal infeksiyonların yaygınlığında bu bakterinin antibiyotik ve antimikrobiyal ilaçlara karşı dünya genelinde oldukça fazla direnç geliştirmiş olması etkili olabilir (Kérouanton ve ark. 2007).

Yüzeyde yapışkanlık oluşturarak gıdaları bozan ve düşük sicaklıkta üreyebilen Pseudomonas spp. deniz ürünlerinde baskın florayı oluşturabilirler (Erkman 2013). Bir çok araștırmacı Pseudomonas spp.'nin kalamar dâhil deniz ürünleri için risk olabileceğini bildirmişlerdir (Vaz-Pires ve Barbosa 2004; Vaz-Pires ve ark. 2008). Balık etinde bulunan proteinler, bakteri kaynaklı proteazlar tarafından kolaylıkla parçalandığından birçok bakterinin gelişmesi için uygun bir ortam olușturmaktadır. Araștırmacılar taze palamutta toplam mezofilik aerobik bakteri $3.14 \mathrm{log} \mathrm{kob} / \mathrm{g}$, toplam maya-küf $2.92 \mathrm{log} \mathrm{kob} / \mathrm{g}$, toplam koliform bakteri $2.71 \mathrm{log} \mathrm{kob} / \mathrm{g}$ düzeyinde, taze hamside ise aynı sıra ile $5.37 \mathrm{log} \mathrm{kob} / \mathrm{g}, 2.81 \mathrm{log} \mathrm{kob} / \mathrm{g}, 2.79 \mathrm{log} \mathrm{kob} / \mathrm{g}$ seviyesinde tespit etmișlerdir (Corapcl 2018). Gou ve ark. (2010), kalamar (Todarodes pacificus) örneklerinde genel hijyen için çok önemli bir belirteç olan toplam bakteri sayısını $3.91 \mathrm{log} \mathrm{kob} / \mathrm{g}$ olarak belirlemișlerdir. Ülkemizde diğer deniz ürünlerine göre daha az avlanan kalamarın mikrobiyal kalitesine yönelik çalışmaların yetersiz kaldığ ve bu alandaki verilerin zenginleștirilmesinin önemli olduğu düşünülmektedir.

$\mathrm{Bu}$ çalışma, Mersin ve Sivas illeri ve çevresinde tüketime sunulan temizlenmiș ve dondurulmuș halde satılan kalamar örneklerinin mikrobiyolojik kalitesini belirlemek ve sonuçları halk sağlığı açısından değerlendirmek amacıyla yapılmıștır.

\section{MATERYAL ve METOT}

\section{Materyal}

Bu çalışmada Mersin ve Sivas illerindeki perakende satış noktalarından alınan ve soğuk zincirle laboratuvara getirilen 100 adet donmuș kalamar örneği (yaklașık olarak $500 \mathrm{~g}$ ağırlığında, $6-8 \mathrm{~cm}$ çapında), $4 \pm 1 \quad{ }^{\circ} \mathrm{C}^{\prime} \mathrm{de}$ çözündürüldükten sonra standart metotlar kullanılarak $E$. coli, S. aureus, L. monocytogenes, Pseudomonas spp. açısından incelenmiştir.

\section{Mikrobiyolojik Analizler}

Örneklerde E. coli tespiti için, hazırlanan seri dilüsyonlardan Chromocult TBX (Tyrptone Bile Xglucoronide Agar; Merck, Darmstadt, Germany) agara yayma yöntemiyle ekim yapılmıștır. İnkübasyon sonrasında besiyerindeki mavi-yeşil renkli koloniler $E$. coli olarak değerlendirilmiştir (ISO 2001). Çalışmamızda, S. aureus'u belirlemek için Baird Parker Agara (Merck, Darmstadt, Germany) seri dilüsyonlardan ekim yapılarak $35 \pm 1{ }^{\circ}$ C'de 48 saat inkübasyona birakılan petrilerde gelişen tüm tipik koloniler sayılmıştır. Tipik kolonilere doğrulama amacı ile koagülaz (Bactident ${ }^{\circledR}$ Coagulase rabbit, Merck, Darmstadt, Germany) testi uygulanmıştır. Gözle görülebilen bir aglütinasyon olușturan koloniler koagülaz (+) S. aureus kabul edilmiştir (Halkman 2005). $L$. monocytogenes analizi, PALCAM (Merck, Almanya) ve OXFORD (Merck, Almanya) agar besiyerleri kullanılarak FDA-BAM metoduna göre yapılmıștır (US-FDA-BAM 2017). Tipik koloniler sayılarak seçilen kolonilerin doğrulaması Mini Vidas (Biomerieux, Fransa) cihazı ile yapılmıștır (Anonim 2017). Pseudomonas spp. sayımı için Cetrimide ilave edilmiş Pseudomonas Agar Base (Oxoid CM0559, İngiltere) besiyeri kullanılmıştır. Ekimi yapılan petriler $25 \pm 1^{\circ} \mathrm{C}^{\prime}$ de 2 gün inkübasyona tabi tutulmuş ve değerlendirilmiștir (Mendes ve ark. 2011).

\section{BULGULAR}

Temizlenip, dondurularak satıșa sunulan 100 adet halka kalamar örneğinin 25 tanesinde E. coli, Pseudomonas spp., L. monocytogenes ve koagülaz (+) S. aureus'a rastlanmıștır. Bakteri tespit edilen örneklere ait değerler Tablo.1'de verilmiştir. Çalışmamızda örneklerin 10'unda (\%10) Pseudomonas spp., 7'sinde (\%7) E. coli, 5'inde (\%5) L. monocytogenes ve 8'inde (\%8) koagülaz (+) S. aureus tespit edilmiştir. Kalamar örneklerinde en yüksek E. coli, Pseudomonas spp. ve koagülaz (+) S. aureus sayısı sirasıyla, $4.7 \times 10^{3} \mathrm{kob} / \mathrm{g}, 7.0 \times 10^{2} \mathrm{kob} / \mathrm{g}$ ve $8.9 \times 10^{2} \mathrm{kob} / \mathrm{g}$ olarak tespit edilmiştir. Kalamarların üç tanesinde (\%3) Pseudomonas spp. ve koagülaz (+) S. aureus'a, başka iki (\%2) örnekte ise Pseudomonas spp. ve E. coli'ye birlikte rastlanmıș olup, diğer örneklerde etkenler ayrı ayrı belirlenmiștir.

\section{TARTIŞMA ve SONUÇ}

Deniz ürünleri ile ilgili araștırma yapan Da Silva ve ark. (2010) Brezilya'da, Oh ve ark. (2007) Kore'de satıș noktalarından sağlanan taze deniz ürünlerini, Simon ve Sanjeev (2007) Hindistan'da satılan donmuş ve kurutulmuş balıkçılık ürünleri çalışmışlardır. Araştırmamızda ise ülkemizdeki iki şehirden sağlanan ve dondurularak satılmakta olan kalamarların mikrobiyal kalitesi ortaya konulmuştur. Analize alınan ve mikrobiyal üreme tespit edilemeyen kalamarların, yakalama ve depolama şartlarının iyi olduğu, üretim aşamasında hijyen kurallarına dikkat edildiği ve sonrasında rekontaminasyon olmadığl, üretimin her aşamasındaki personelin kişisel hijyene dikkat ettiği ve uygulanan iyi bir gida güvenliği sisteminin olduğu düşünülmektedir. İnsanlarda, kontamine gidalardan kaynaklanan birçok hastalık görülmekte ve bu hastalıklar özellikle hassas gruplarda (yaşlılar, çocuklar vb.) ölümle sonuçlanabilmektedir. 
Su ürünleri yakalanması, üretilmesi, depolanması ve satışı sırasında mikrobiyal risklere açıtır (Ito ve ark. 2015). Bu nedenle düşük sıcaklıkta depolama işlemiyle mikrobiyal bozulma engellenerek ürünün raf ömrü uzatılabilir (Wang ve ark. 2003). Nitekim kalamar (Todarodes pacificus) örneklerinin soğuk muhafaza şartlarında 12 gün depolanmasıyla toplam bakteri sayısı $3.37 \mathrm{log} \mathrm{kob} / \mathrm{g}$ artabilmektedir (Gou ve ark. 2010). Satış noktalarında kalamarların soğutulmuş olarak değil de dondurularak satılması ve bunun kontrol edilmesi gida kalitesi ve güvenliği, halk sağlığı ve işletme ekonomisi açısından önem arz etmektedir.

L. monocytogenes soğuk muhafazaya alınan gıdalarda da üreyebildiği için deniz ürünleri sanayi açısından risk teşkil etmektedir. $\mathrm{Bu}$ nedenle birçok ülkede gıdalarda hiç bulunmaması yönünde kararlar alınmıștır. Deniz suyu ve deniz canlılarında $L$. monocytogenes ve $S$. aureus kontaminasyonu ciddi boyutlara ulașmıștır. Son yıllarda Japon Denizi ve Güney Çin Denizi'nde; deniz suyu ve canlılarında L. monocytogenes sayısı sırasıyla, \%5.9 ve 5.8 oranında tespit edilmistir, $S$. aureus sayısı ise sırasıyla, $\% 9.3$ ve \%20.4 olarak belirlenmiștir (Beleneva 2011). Çalışmamızda incelediğimiz örneklerin 5'inde (\%5) L. monocytogenes ve 8'inde (\%8) koagülaz (+) S. aureus tespit edilmesi kontaminasyonu ortaya koymaktadır. $L$. monocytogenes dondurulmuş ürünlerin çözündürülüp dondurulması ya da raflarda isı suistimalinin olması durumunda çoğalabildiğinden gıda sektörü açısından önem arz etmektedir (Atasever 2011).

EFSA'nın 2010 yılında yayınladığı rapora göre $S$. aureus, Avrupa Birliği'nde balık ve balıkçılık ürünlerinde en fazla gıda salgınına sebep olan üçüncü bakteridir (EFSA 2010). Gıda ve çevre örneklerinde sıkça rastlanan $S$. aureus gıda işletmelerinde çalışan kişilerin saç ve derilerinden aynı zamanda ağız ve burunlarından ürünlere bulaşabilmektedir. S. aureus çevresel şartlara dayanıksız olmasına rağmen, bu bakteri tarafında üretilen toksinler bașta ıSı olmak üzere birçok faktöre karşı dayanıklıdır (Omoe ve ark. 2005).

Tablo 1. Dondurulmuş kalamar (Todarodes pacificus) örneklerinin mikrobiyolojik analiz bulguları (n=100)

Table 1. Microbiological analysis findings of frozen squid (Todarodes pacificus) samples ( $\mathrm{n}=100)$

\begin{tabular}{|c|c|c|c|c|c|}
\hline & $\begin{array}{l}\text { E. coli } \\
\text { (kob/g) }\end{array}$ & $\begin{array}{l}\text { Pseudomonas } \\
\text { (kob/g) }\end{array}$ & spp. & $\begin{array}{l}\text { Koagülaz (+) } S . \\
\text { aureus }(\mathrm{kob} / \mathrm{g})\end{array}$ & $\begin{array}{l}\text { L. monocytogenes } \\
\text { (Var-Yok/25 g) }\end{array}$ \\
\hline 1 & $<10$ & $<10$ & & $<10$ & Tespit edildi \\
\hline 2 & $<10$ & $5.0 \times 10^{1}$ & & $4.4 \times 10^{2}$ & Tespit edilemedi \\
\hline 3 & $4.2 \times 10^{3}$ & $7.0 \times 10^{2}$ & & $<10$ & Tespit edilemedi \\
\hline 4 & $<10$ & $<10$ & & $<10$ & Tespit edildi \\
\hline 5 & $<10$ & $<10$ & & $4.0 \times 10^{2}$ & Tespit edilemedi \\
\hline 6 & $2.2 \times 10^{2}$ & $<10$ & & $<10$ & Tespit edilemedi \\
\hline 7 & $<10$ & $1.0 \times 10^{2}$ & & $4.0 \times 10^{2}$ & Tespit edilemedi \\
\hline 8 & $<10$ & $<10$ & & $7.1 \times 10^{2}$ & Tespit edilemedi \\
\hline 9 & $5.5 \times 10^{2}$ & $<10$ & & $<10$ & Tespit edilemedi \\
\hline 10 & $<10$ & $2.0 \times 10^{2}$ & & $<10$ & Tespit edilemedi \\
\hline 11 & $<10$ & $2.0 \times 10^{2}$ & & $<10$ & Tespit edilemedi \\
\hline 12 & $<10$ & $3.3 \times 10^{2}$ & & $5.0 \times 10^{2}$ & Tespit edilemedi \\
\hline 13 & $<10$ & $<10$ & & $<10$ & Tespit edildi \\
\hline 14 & $1.7 \times 10^{3}$ & $3.0 \times 10^{2}$ & & $<10$ & Tespit edilemedi \\
\hline 15 & $<10$ & $<10$ & & $1.6 \times 10^{2}$ & Tespit edilemedi \\
\hline 16 & $9.4 \times 10^{2}$ & $<10$ & & $<10$ & Tespit edilemedi \\
\hline 17 & $<10$ & $1.1 \times 10^{2}$ & & $<10$ & Tespit edilemedi \\
\hline 18 & $<10$ & $<10$ & & $1.0 \times 10^{2}$ & Tespit edilemedi \\
\hline 19 & $<10$ & $<10$ & & $<10$ & Tespit edildi \\
\hline 20 & $<10$ & $6.0 \times 10^{2}$ & & $<10$ & Tespit edilemedi \\
\hline 21 & $4.7 \times 10^{3}$ & $<10$ & & $<10$ & Tespit edilemedi \\
\hline 22 & $<10$ & $<10$ & & $8.9 \times 10^{2}$ & Tespit edilemedi \\
\hline 23 & $<10$ & $<10$ & & $<10$ & Tespit edildi \\
\hline 24 & $<10$ & $5.2 \times 10^{2}$ & & $<10$ & Tespit edilemedi \\
\hline 25 & $5.0 \times 10^{2}$ & $<10$ & & $<10$ & Tespit edilemedi \\
\hline
\end{tabular}


Muhafaza koșulları bakterinin üremesinde çok etkili olduğundan depolama șartlarına dikkat edilmelidir. Zira bakteri sayısı $10^{6} \mathrm{kob} / \mathrm{g}-\mathrm{ml}$ düzeyine geldiğinde toksin üretilmektedir. Çalışmamızda örneklerin 8'inde (\%8) koagülaz (+) S. aureus tespit edilmiștir. Ancak $10^{6} \mathrm{kob} / \mathrm{g}$ düzeyine ulaşan bir kontaminasyon tespit edilememiștir. $\mathrm{Bu}$ sonuç kalamarın $S$. aureus açısından risk teșkil edebileceği anlamına gelmektedir. Öztürk ve Gündüz (2018a) analize aldıkları çiğ su ürünlerinin \%58'inde, tüketime hazır su ürünlerinin ise \%26'sında koagülaz pozitif $S$. aureus tespit etmişlerdir. González-Rodríguez ve ark. (2002), tütsülenmiş-soğutulmuş ve vakum paketlenmiş tatlı su balıklarında yaptıkları çalışmada 54 örneğin 3'ünün(\%5.5) S. aureus ile kontamine olduğunu bildirmișlerdir. Normanno ve ark. (2005), çiğ tüketilen İtalyan balıkçlık ürünlerinde (mürekkepbalığı vb.) bu oranı \%10 olarak belirtmişlerdir. Araştırmaya konu olan su ürünlerinin farklılı̆̆ ve avlanma, ișleme, muhafaza şartları gibi değişkenlerin oransal farklılığa etki ettiği düşünülmektedir. Bu riski elimine etmek için kurutulmuş kalamara "corona discharge plasma" tekniği uygulanmıș ve S. aureus sayısında $0.9 \mathrm{log}$, toplam bakteride 2.0 log azalma sağlanmıștır (Choi ve ark. 2017).

Taze su ürünleri yakalandıkları ortama bağlı olarak değişik oranlarda bakteri ile kontamine olabilir. Ancak uygun şartlarda muhafaza edilmeleri ve ișlenmeleri ile bu risk minimize edilebilmektedir (Herrera ve ark. 2006). Su ürünlerinin doğal floranın parçası olmayan stafilokokların varlığı yakalanma, üretim, işleme, paketleme, satış ve servis așamalarında kontaminasyonu ișaret eder. Simon ve Sanjeev (2007), balıkçlılk sektöründe çalıșan ișçilerin \%62'sinin enterotoksijenik $S$. aureus yönünden pozitif olduğunu tespit etmişlerdir. Onmaz ve ark. (2015), satış noktalarından temin edilen balıklarda(hamsi, alabalık, çipura) bu oranı \%30 olarak belirlemișlerdir. Herrera ve ark. (2006), S. aureus görülme sıklığını taze su ürünlerinde $\% 43$ donmuş su ürünlerinde ise $\% 30$ düzeyinde belirlemiștir. Zerai ve ark. (2012), dondurulmuş karides ve çiğ balık örneklerinin \%17.5'inde $S$. aureus tespit etmișlerdir. $\mathrm{Bu}$ araștırmacılar tarafindan taze ve dondurulmuş ürünlerin füme, tuzlanmış ve hazır pişmiş su ürünlerinden daha fazla $S$. aureus riski taşıdığı belirtilmiștir. Araștırmamızda ise kalamar örneklerinin \%8'inde koagülaz (+) S. aureus tespit edilmiştir. Çalışmalar arasındaki farklılıkların üretim tekniklerinden, numune sayısı ve izolasyon metodunun farklılığından kaynaklanabileceği düşünülmektedir.

Öztürk ve Gündüz (2018b), ısıl işlem görmüş midye dolmalarında $S$. aureus sayısının $<2.00-5.04 \mathrm{log} \mathrm{kob} / \mathrm{g}$, Kök ve ark. (2015) ise $S$. aureus sayısını 2-4.55 kob/g olarak belirlemişlerdir. Bir gidada $S$. aureus varlığı, uygun olmayan ișleme prosesine ve çapraz bulașma olasılığına işaret ettiğinden (Kışla ve Üzgün 2008), örneklerimizin \%8'inde koagülaz (+) S. aureus tespit edilmiș olması, ișlem görmüș deniz ürünlerinde kontaminasyon olabileceğini ortaya koymaktadır. Buz $\left(2 \pm 2{ }^{\circ} \mathrm{C}\right)$ içerisinde tutulan kalamarların bașlangıçta $10^{2}-10^{3} \mathrm{kob} / \mathrm{cm}^{2}$ olan genel canlı sayısı 12-13. günlerde $10^{4} \mathrm{kob} / \mathrm{cm}^{2}$ sayısına ulaşmış, aynı șartlarda Pseudomonas ise $4.5 \mathrm{log} \mathrm{kob} / \mathrm{cm}^{2}$ düzeyinde tespit edilmiştir. Başlangıçta düşük seyreden genel canlı sayısının 10. günden sonra hızla arttığı Pseudomonas'ın ise depolamanın 6. gününden sonra ciddi düzeyde arttığı belirlenmiştir. Kalamar örneklerinde Enterobacteriaceae sayısının oldukça düșük $\left(0.5 \log \mathrm{kob} / \mathrm{cm}^{2}\right)$ olduğu ve bunun da önemli olmadığı ifade edilmiștir (Vaz-Pires ve ark. 2008). Vaz-Pires ve Barbosa (2004), ahtapot örneklerinde $2.7 \log \mathrm{kob} / \mathrm{g}$ düzeyinde Pseudomonas belirlendiğini, bu sayının 3 log kob/g düzeyine ulaștığında duyusal bozukluğun bașladığını belirtmistir Çalışmamızdaki kalamar örneklerinde bu düzeyin altında (1.0x102-7.0x10²) Pseudomonas spp. tespit edilmiştir.

Diğer deniz ürünlerinde olduğu gibi kalamarında satışında ve kabul edilebilirliğinde duyusal mikrobiyolojik ve kimyasal nitelikleri ön plana çıkmaktadır. Huss (1998)'e göre, bakterilerin balıkların kas dokusuna geçebilmesi için $10^{6} \mathrm{kob} / \mathrm{cm}^{2}$ düzeyine ulașması gerekmektedir. Kalamarın da içinde bulunduğu kafadan bacaklılarda enzimatik aktivite çok hızlı olduğundan bakteriler derin dokulara ulaşacak kadar çoğalamayabilir. Çalıșmamızda bazı örneklerde bakterilerin çok az tespit edilmesi ya da hiç tespit edilememiş olması bu teori ile uyumludur. Kalamar örneklerinin mikrobiyal yükünün farklı olmasında, yakalandıkları ya da yetiștirildikleri suların yanı sıra depolama, ișleme ve satış noktalarının farklı hijyenik şartlarda olması ve üretimde çalıșan kișilerin temizlik anlayıșlarının değișken olmasının etkisi olabilir (Vaz-Pires ve Barbosa 2004). Ayrıca kalamardaki yüksek su aktivitesi $(\geq 0.98)$ ve nötre yakın $\mathrm{pH}(\geq 6.0)$ mikrobiyal gelișim için diğer deniz ürünlerinden daha uygun ortam olușturmaktadır (Erol 2007; Erkman 2013). Deniz ürünlerinde hijyen, yakalandığı andan itibaren gemilerde başlayan ve işleme aşamalarını takiben satış noktalarında devam eden bir süreçtir. Kalamarlar mikrobiyal açıdan iyi olan sularda yakalanmış olsa bile ișleme ve paketleme sırasında sekonder ve çapraz kontaminasyonla bașta $E$. coli olmak üzere birçok bakteri ile bulaşmıș olabilir. E. coli, gıdaya üretim ve muhafaza sirasında personelden, hammaddeden, alet ve ekipmandan bulașabilmektedir. Çalıșmamızda incelenen dondurulmuș kalamarların \%7'sinde $\left(2.2 \times 10^{2}-4.7 \times 10^{3}\right) \quad E$. coli tespit edilmiştir. Gıdalarda E. coli tespiti bağırsak kaynaklı kontaminasyona ve işletmelerde uygulanan sanitasyonun yetersiz olduğuna ișaret etmektedir.

Dondurma işlemi ile balıktaki mikrobiyal yük azaltılmasına rağmen ürünlerde belirli sayı da bakteri bulunabilmektedir. Vaz-Pires ve ark. (2008) 13 gün boyunca buzda depolanan kalamarların (Illex coindetii) Enterobacteriaceae sayısının $0.5 \quad \log \mathrm{kob} / \mathrm{cm}^{2}{ }^{\prime} \mathrm{yi}$ geçmediğini bildirmişlerdir. Dondurularak (-22 $\left.{ }^{0} \mathrm{C}\right)$ muhafaza edilen bazı deniz balıklarında (Hamsi ve Palamut) 12 aylık depolama sonunda dahi toplam mezofilik aerobik bakteri Palamutta 2.90 log kob/g, hamside $3.28 \mathrm{log} \mathrm{kob} / \mathrm{g}$, toplam maya-küf ise aynı sırayla $2.69 \mathrm{log} \mathrm{kob} / \mathrm{g}, 2.54 \mathrm{log} \mathrm{kob} / \mathrm{g}$ düzeyinde belirlenmiștir (Corapcl 2018). Ben-Gigirey ve ark.(1998), -25 oC'de ve -18 oC'de 9 ay süreyle muhafaza edilen beyaz ton balıklarında (Thunnus alalunga) mikrobiyal yükte azalma olduğunu bildirmişlerdir. Araştırmamızda kullandığımız dondurulmuş kalamar örneklerinin 1/4'ünün değişik bakterilerle kontamine olduğu belirlenmiștir.

Sonuc olarak, her gıda maddesi gibi kalamarlarda üretim, depolama, satış ve servis sırasında değișik düzeylerde mikrobiyal kontaminasyona maruz kalabilmektedir. Elde edilen bulgularla kalamarlarda çapraz bulașmaların olabileceği ve temas eden personelin kișisel temizliğine dikkat etmediği belirlenmiștir. Araștırma sonucunda kalamar örneklerinin patojen (\%5 L. monocytogenes) bakteriler açısından risk taşıyabileceği ortaya konulmuștur. Mikrobiyolojik açıdan daha iyi dondurulmuș kalamar üretmek için işletmelerde gıda güvenliği sistemleri etkin bir şekilde uygulanmalı, çalışan personel gerekli hijyen bilgisi ile donatılmalı ve soğuk zincire dikkat edilmelidir. Halk sağlığı açısından risk grubu gıdalar içerisinde değerlendirebileceğimiz deniz ürünlerinin düzenli kontrollerinin sıklıkla yapılması ve tüketicinin 
deniz ürünlerinden kaynaklanabilecek sorunlarla ilgili bilgilendirilmesi önerilmektedir.

\section{ÇIKAR ÇATIŞMASI}

Yazarlar, çıkar çatışması olmadığını beyan eder.

\section{KAYNAKLAR}

Anonim (2017). viDAS. Biomerieux Vidas protokolü. VIDAS LMO2 AFNOR BIO-12/11-03/04).

Atasever MA (2011). Kiymalarda bazı patojenlerin izolasyon ve identifikasyonu. Tez (Doktora). Atatürk Üniversitesi, Sağlık Bilimleri Enstitüsü.

Beleneva IA (2011). Incidence and characteristics of Staphylococcus aureus and Listeria monocytogenes from the Japan and South China seas. Mar Pollut Bull, 62, 382-387.

Ben-Gigirey B, Sousa JMVB, Villa TG, Barros-Velazquez J (1998). Changes in biogenic amines and microbiological analysis in albacore (Thunnus alalunga) muscle during frozen storage. J Food Prot, 61, 608615.

Bogdanovicova K, Necidova L, Harustiakova D, Janstova B (2017). Milk powder risk assessment with Staphylococcus aureus toxigenic strains. Food Control, 73, 2-7.

Choi KD, Park UY, Shin IS (2012). Microbial contamination of seasoned and dried squid Dosidicus gigas during processing. Korean J Fish Aquat Sci, 45, 445-453.

Choi S, Puligundla P, Mok C (2017). Effect of corona discharge plasma on microbial decontamination of dried squid shreds including physicochemical and sensory evaluation. LWT - Food Sci Technol, 75, 323-328.

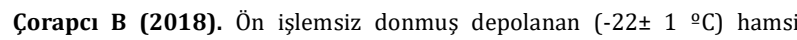
(Engraulis encrasicolus, Linnaeus 1758) ve palamut (Sarda sarda, Bloch 1793) balıklarının duyusal, besinsel, kimyasal ve mikrobiyolojik özellikleri. Glda, 43, 1075-1090.

Da-Silva ML, Matté GR, Germano PML, Matté MH (2010). Occurrence of pathogenic microorganisms in fish sold in São Paulo, Brazil. J Food Safety, 30, 94-110.

Deng Y, Wang Y, Song X, Huang H, Qian B, Zhang H (2012). Changes in soluble protein and antioxidant property of squid (Illex illecebrosus LeSueur) fillets dried in a heat pump dryer using far-infrared radiation. Philipp Agric Sci, 95, 386-393.

EFSA (2010). European Centre for Disease Prevention and Control, 2010. The community summary report on trends and sources of zoonoses, zoonotic agents and food-borne outbreaks in the European Union in 2008. EFSA Journal, 8, 1496.

Erkman 0 (2013). Gida Mikrobiyolojisi. Efil Yayınevi, Ankara.

Erol İ (2007). Gıda Hijyeni ve Mikrobiyolojisi. Pozitif Matbaacılık, Ankara.

Fenlon DR (1999). Listeria monocytogenes in the natural environment. In "Listeria, Listeriosis and Food Safety", (Ed), Ryser ET, Marth EH, Marcel Dekker Inc., New York, USA.

González-Rodríguez MN, Sanz JJ, Santos JA, Otero A, García-López, ML (2002). Numbers and types of microorganisms in vacuum-packed cold-smoked freshwater fish at the retail level. Int J Food Microbiol, 77 161-168.

Gou J, Lee HY, Ahn J (2010). Effect of high pressure processing on the quality of squid (Todarodes pacificus) during refrigerated storage. Food Chem, 119, 471-476.

Halkman K (2005). Merck Mikrobiyoloji El Kitabı. Başak Matbaacılık, Ankara.

Herrera FC, Santos JA, Otero A, García-López ML (2006). Occurrence of foodborne pathogenic bacteria in retail prepackaged portions of marine fish in Spain. J Appl Microbiol, 100, 527-536.

Huss HH (1998). El pescado fresco: su calidad y cambios de su calidad. [FAO Documento Te'cnico de Pesca No. 348]. Food and Agriculture Organization, Rome, Italy.

International Organization for Standardization (ISO 16649-2) (2001). Microbiology of food and animal feding stuffs - Horizontal method for the enumeration of beta-glucuronidase-positive Escherichia coli - Part 2: Colony-count technique at 44 degrees $\mathrm{C}$ using 5-bromo-4-chloro-3indolyl beta-D-glucuronide.

Ito M, Shiozaki A, Shimizu M, Saito S (2015). Hemolytic- uremic syndrome with acute encephalopathy in a pregnant woman infected with epidemic enterohemorrhagic Escherichia coli: characteristic brain images and cytokine profiles. Int J Infect Dis, 34, 119-121.
Kérouanton A, Hennekinne JA, Letertre C, et al. (2007). Characterization of Staphylococcus aureus strains associated with food poisoning outbreaks in France. Int J Food Microbiol, 115, 369-375.

Kıșla D, Üzgün Y (2008). Microbiological evaluation of stuffed mussels. J Food Prot, 71, 616-620.

Kök F, Şahiner C, Koçak P, Göksoy EÖ, Beyaz D, Büyükyörük S (2015). Determination of microbiological quality of stuffed mussels sold in Aydın and İzmir. MANAS J Eng, 3, 70-76.

Lee ES, Park SY, Ha SD (2015). Effect of UV-C light on the microbial and sensory quality of seasoned dried seafood. Food Sci Technol Int, 22, 213-220.

Liston J (1990). Microbial hazards of seafood consumption toxins, bacteria and viruses are the principal causes of sea foodborne diseases. Food Technol, 44, 58-62.

Mendes R, Silva HA, Anacleto P, Cardoso C (2011). Effect of $\mathrm{CO}_{2}$ dissolution on the shelf life of ready-to-eat Octopus vulgaris. Innov Food Sci Emerg, 12, 551-561.

Normanno G, Firinu A, Virgilio S, et al. (2005). Coagulase-positive Staphylococci and Staphylococcus aureus in food products marketed in Italy. Int J Food Microbiol, 98, 73-79.

Oh SK, Lee N, Cho YS, Shin DB, Choi SY, Koo M (2007). Occurrence of toxigenic Staphylococcus aureus in ready-to-eat food in Korea. J Food Protect, 70, 1153-1158.

Omoe K, Dong-Liang H, Takahashi-Omoe H, Nakane A, Shinagawa K (2005). Comprehensive analysis of classical and newly described staphylococcal superantigenic toxin genes in Staphylococcus aureus isolates. FEMS Microbiol Lett, 246, 191-198.

Onmaz NE, Abay S, Karadal F, Hizlisoy H, Telli N, Al S (2015). Occurence and antimicrobial resistance of Staphylococcus aureus and Salmonella spp. in retail fish samples in Turkey. Mar Pollut Bull, 90, 242-246.

Öztürk F, Gündüz H (2018a). İzmir'de satışa sunulan su ürünlerinde koagülaz pozitif Staphylococcus aureus'un insidansı ve antibiyotik direnci. Glda, 43, 313-320.

Öztürk F, Gündüz H (2018b). Tüketime hazır midye dolmaların mikrobiyolojik kalitelerinin belirlenmesi. Gıda, 43, 745-750.

Rendueles E, Omer MK, Alvseike O, Alonso-Calleja C, Capita R, Prieto M (2011). Microbiological food safety assessment of high hydrostatic pressure processing: a review. LWT-Food Sci Technol, 44, 1251-1260.

Rocourt J, Cossart P (1997). Listeria monocytogenes. In: "Food Microbiology-Fundamentals and Frontiers", (Ed), Doyle MP. Buechat LR, Montville TJ, American Society for Microbiology (ASM) Press, Washington DC.

Rodas-Suárez OR, Flores-Pedroche JF, Betancourt-Rule JM, QuiñonesRamírez EI, Vázquez-Salinas C (2006). Occurrence and antibiotic sensitivity of Listeria monocytogenes strains isolated from oysters, fish, and estuarine water. Appl Environ Microb, 72, 7410-7412.

Simon SS, Sanjeev S (2007). Prevalence of enterotoxigenic Staphylococcus aureus in fishery products and fish processing factory workers. Food Control, 18, 1565-1568.

Teplitski M, Wrigh AC, Lorca G (2009). Biological approaches for controlling shellfish-associated pathogens. Curr Opin Biotechnol, 20, $185-190$.

Türkiye İstatistik Kurumu (2019). Avlanan diğer deniz ürünleri (kabuklu, yumuşakçalar) miktarı.

US-FDA (2017). Bacteriological Analytical Manual, Chapter 10: Detection of Listeria monocytogenes in foods and environmental samples, and enumeration of Listeria monocytogenes in foods.

Vázquez-Sánchez D, López-Cabo M, Saá-Ibusquiza P, RodríguezHerrera JJ (2012). Incidence and characterization of Staphylococcus aureus in fishery products marketed in Galicia (Northwest Spain). Int J Food Microbiol, 157, 286-296.

Vaz-Pires P, Barbosa A (2004). Sensory, microbiological, physical and nutritional properties of iced whole common octopus (Octopus vulgaris). LWT - Food Sci Technol, 37, 105-114.

Vaz-Pires P, Seixas P, Mota M, et al. (2008). Sensory, microbiological, physical and chemical properties of cuttlefish (Sepia officinalis) and broadtail shortfin squid (Illex coindetii) stored in ice. LWT - Food Sci and Technol, 41, 1655-1664.

Wang H, Liceaga-Gesualdo AM, Li-Chan ECY (2003). Biochemical and physical characteristics of muscle and natural actomyosin isolated from young Atlantic salmon (Salmo salar) fillets stored at 0 and $4{ }^{\circ} \mathrm{C} . J$ Food Sci, 68, 784-789.

Zarei M, Maktabi S, Ghorbanpour M (2012). Prevalence of Listeria monocytogenes, Vibrio parahaemolyticus, Staphylococcus aureus, and Salmonella spp. in seafood products using Multiplex Polymerase Chain Reaction. Foodborne Pathog Dis, 9, 108-112. 